\title{
Optimization of medium composition for propagation of recombinant Escherichia coli
}

\author{
Sabina Lipničanová ${ }^{1, \bowtie}$, Daniela Chmelová ${ }^{1}$, Andrej Godány ${ }^{2}$ and Miroslav Ondrejovič ${ }^{1}$ \\ ${ }^{1}$ Department of Biotechnology, Faculty of Natural Sciences, University of SS. Cyril and Methodius in Trnava, Nám. J. Herdu \\ 2, Trnava 91701, Slovak Republic \\ ${ }^{2}$ Department of Biology, Faculty of Natural Sciences, University of SS. Cyril and Methodius in Trnava, Nám. J. Herdu 2, \\ Trnava 91701, Slovak Republic
}

\section{Article info}

\section{Article history:}

Received: $18^{\text {th }}$ September 2019

Accepted: $14^{\text {th }}$ November 2019

\section{Keywords:}

Bacteria

Biomass

Neuraminidase

Plasmid DNA

Propagation

Response Surface Methodology

\section{Abbreviations:}

DCW - dry cell weight

DNS - 3,5-dinitrosalicylic acid

$\mathrm{HA}$ - hemagglutinin

LB - Luria-Bertani

$\mathrm{NA}$ - neuraminidase

OD - optical density

pDNA - plasmid DNA

PBS - phosphate-buffered saline

RSM - Response Surface Methodology

TB - terrific broth

\begin{abstract}
Recombinant protein production in heterologous hosts often seems a simpler and more effective way than its production by natural producer. The secretion of recombinant protein in Escherichia coli has many advantages comparing to than in insect or mammalian cells. The important factor for high-level recombinant protein production is the sufficient amount of $E$. coli biomass. Therefore, the aim of this study was to optimize the composition of propagation medium resulting in the maximum biomass yield of recombinant E. coli as the part of fermentation strategy for neuraminidase (NA) production. Three independent variables including glucose, asparagine and phosphate concentrations, and four dependent variables, such as biomass yield, residual concentrations of glucose or asparagine and $\mathrm{pH}$ of the propagation medium after fermentation, were chosen to the optimization by Response Surface Methodology (RSM). The optimal conditions for the maximum biomass yield expressed as dry cell weight (DCW) $\left(16.57 \pm 0.55 \mathrm{~g} \mathrm{DCW}^{-1} \mathrm{D}^{-1}\right)$ were as follows: glucose concentration of $39.37 \mathrm{mM}$, asparagine concentration of $62.68 \mathrm{mM}$ and phosphate concentration of $14.80 \mathrm{mM}$. For this model, the predicted values for the responses are close to the experimental values. The yield of desired pET15b-neu plasmid from $E$. coli cells cultivated in optimized propagation medium was almost $23 \%$ higher than in commonly used Luria-Bertani (LB) medium suggesting that asparagine may be involved in the induction of plasmid amplification.
\end{abstract}

(C) University of SS. Cyril and Methodius in Trnava

\section{Introduction}

The recombinant production of desired protein can facilitate product isolation and impact its quality and activity (Horga et al. 2018). The choice of suitable host affects the whole process. Among microorganisms, bacteria have been widely used as the hosts for high-level expression of protein (Nikerel et al. 2006). The use of gram-negative bacterial host Escherichia coli has several advantages, namely the simplicity of system, fast growth linked to high cell density and cost-effective cultivation to produce recombinant protein at a relative high level (Fakruddin et al. 2012; Rosano and Ceccarelli 2014).

Usually, the production of recombinant protein by $E$. coli host cells is two-step process. In the first step, the cells are cultivated in a simple, defined medium with a carbon source that suppresses gene expression and results in the accumulation of biomass (Potvin et al. 2012; Celik et al. 2012). The induction of recombinant protein synthesis is 
initiated by the addition of an inducer of promoter after the depletion of carbon source in the second step of production strategy. The biomass yield can be affected by the composition of production medium leading to high-level production of heterologous protein (Sekar et al. 2018). Thus, the yield of recombinant protein may be proportional to the final biomass production. The optimization of the propagation medium composition by the Response Surface Methodology (RSM) is the suitable tool to increase the amount of host biomass (Nikerel et al. 2006; Ghosalkar et al. 2008). The sufficient biomass yield is the part of fermentation strategy for the production of neuraminidase (NA) in E. coli host cells harbouring plasmid pET15b with gene for influenza virus NA (pET15b-neu). NA as a surface glycoprotein of influenza virus has an essential role in the infectious cycle of the virus (Doyle et al. 2013). Screening of new NA inhibitors requires enzymatically active NA which can be obtained by synthesis using recombinantly modified organisms such as E. coli (Nallaiyan et al. 2010). Inhibition of this enzyme through drug additives is a perspective way to cure of diseases caused by influenza virus (Doyle et al. 2013; Udommaneethanakit et al. 2014; Hadzázi et al. 2018).

The aim of this study was to optimize the composition of propagation medium by RSM to improve E. coli biomass yield leading to highlevel production of recombinant NA as the perspective tool for design of novel antiviral compounds.

\section{Experimental}

\section{Bacterial strain, media and culture conditions}

Bacteria of Escherichia coli strain BL21 (DE3)pLys $\left(\mathrm{F}^{-}\right.$omp $\mathrm{T} \mathrm{hsdS}_{\mathrm{B}} \quad\left(\mathrm{r}_{\mathrm{B}}^{-}, \mathrm{m}^{-}\right)$gal dcm (DE3) pLysS $\left(\mathrm{Cam}^{\mathrm{R}}\right)$ ) were obtained from Agilent Technologies (USA). The gene coding for NA was developed through the design using the sequence deposited in GenBank (accession No. KM244086.1) and synthesized (ATG Biosynthetic, Germany).

Propagation medium was inoculated with $E$. coli cell suspension at 2.0 McFarland turbidity in the ratio of 50:1 (v/v) and incubated for 24 hours at $120 \mathrm{rpm}$. E. coli cell suspension was prepared from cells growing in LB (Luria-Bertani) medium (10 g.L $\mathrm{L}^{-1}$ tryptone, 5 g. $\mathrm{L}^{-1}$ yeast extract, 10 g.L $\mathrm{L}^{-1}$ $\mathrm{NaCl}$ and $50 \mathrm{mg} . \mathrm{L}^{-1}$ ampicillin) at $140 \mathrm{rpm}$ and $37^{\circ} \mathrm{C}$ overnight. Bacteria were transformed with the pET15b plasmid harbouring gene for influenza virus NA by the standard protocol.

Basal propagation medium for the cultivation of recombinant $E$. coli consisted of $4 \mathrm{mM}$ glucose, $9 \mathrm{mM}\left(\mathrm{NH}_{4}\right)_{2} \mathrm{SO}_{4}, \quad 10 \mathrm{mM} \mathrm{NaH} \mathrm{PO}_{4}, \quad 10 \mathrm{mM}$ $\mathrm{Na}_{2} \mathrm{HPO}_{4}, 2.5 \mathrm{mM} \mathrm{MgSO}_{4} .7 \mathrm{H}_{2} \mathrm{O}, 34 \mathrm{mM} \mathrm{NaCl}$ and the trace element solution $\left(5 \mathrm{~mL} . \mathrm{L}^{-1}\right)$. The latter was composed of $\mathrm{FeSO}_{4} \cdot 7 \mathrm{H}_{2} \mathrm{O}$, $\mathrm{CoSO}_{4} \cdot 7 \mathrm{H}_{2} \mathrm{O}, \quad \mathrm{ZnCl}_{2}, \quad \mathrm{CuSO}_{4}, \quad \mathrm{Na}_{2} \mathrm{MoO}_{4} \cdot 2 \mathrm{H}_{2} \mathrm{O}$, $\mathrm{H}_{3} \mathrm{BO}_{3}, \quad \mathrm{NiCl}_{2}, \quad \mathrm{MnSO}_{4}$ and $\mathrm{Al}_{2}\left(\mathrm{SO}_{4}\right)_{3}$ at the concentration of $1 \mathrm{~g} . \mathrm{L}^{-1}$ of each compound, as recommended by Sartorius (Sartorius AG, Germany) The $\mathrm{pH}$ of propagation media was adjusted to $\mathrm{pH} 7.1$ with $1 \mathrm{M} \mathrm{NaOH}$ and carbon source was sterilized separately. In preliminary experiments, the type of carbon (glucose, fructose or lactose) and nitrogen sources (ammonium sulfate or asparagine) in the concentration of $100 \mathrm{mM}$ were tested. The effect of different concentrations of carbon and nitrogen sources (glucose and asparagine, respectively) in the range of $0-$ $100 \mathrm{mM}$ and phosphate concentration in the range of $0-64 \mathrm{mM}$ on biomass yields were determined.

Table 1. Levels of the factors tested in RSM.

\begin{tabular}{lrrrrr}
\hline \multirow{2}{*}{$\begin{array}{l}\text { Factor and its } \\
\text { concentration }[\mathrm{mM}]\end{array}$} & -1.682 & -1 & 0 & 1 & 1.682 \\
\cline { 2 - 6 } & 23.18 & 30 & 40 & 50 & 56.82 \\
Glucose & 26.36 & 40 & 60 & 80 & 93.64 \\
Asparagine & 7.27 & 10 & 14 & 18 & 20.73 \\
Phosphate & & \multicolumn{5}{c}{ Level code } \\
\hline
\end{tabular}

\section{Experimental design}

The RSM was used to investigate the effect of glucose, asparagine and phosphate concentrations on the biomass yield expressed as dry cell weight (DCW), residual glucose and asparagine concentrations and final $\mathrm{pH}$ of propagation medium (dependent variables). The variables were tested on five level codes $(-1.682,-1,0,1,1.682)$ and are listed in Table 1.

The analysis of measured data was statistically evaluated by regression method according to Eq. 1:

$Y=b_{0}+\sum_{i-1}^{k} b_{i} X_{i}+\sum_{i-1}^{k} b_{i i} X_{i}^{2}+\sum_{\substack{i-1 \\ i<j}}^{k-1} \sum_{j-2} b_{i j} X_{i} X_{j}$ 
where $X_{i}$ are independent variables causing the $Y$ response and $b_{i}$ are regression coefficients describing dependences between measured properties and coded values of observed factors.

After $8 \mathrm{~h}$ of cultivation, samples were centrifuged at 10,000 rpm for $5 \mathrm{~min}$. In the supernatant, the final $\mathrm{pH}$ was determined, and residual carbon and nitrogen concentrations were analysed by DNS (3,5-dinitrosalicylic acid) method (Miller 1959) and ninhydrin reaction (Kendall 1963), respectively. The sediment was washed, centrifuged and dried at $60{ }^{\circ} \mathrm{C}$ to the constant weight. Biomass yield was expressed as DCW per liter of medium.

\section{Extraction of plasmid DNA}

Plasmid DNA (pDNA) was extracted using the GeneJET Plasmid Miniprep kit (ThermoFisher Scientific, USA) from $E$. coli biomass produced at $37^{\circ} \mathrm{C}$ in optimized propagation and LB media. After extraction, the concentration of pDNA were measured by UV-Vis spectrophotometer (V-1600PC, VWR, Germany) and the result was calculated according to the Eq. 2.

$c\left[\mu g \cdot g^{-1}\right]=\frac{\left(\left(A_{260 n m}-A_{230 n m}\right) * \text { dilution factor } * 50 \mu g \cdot m L^{-1}\right)}{\text { biomass }[g]}$

\section{Statistical analysis}

All experiments carried out in three parallels. Data are present as the average with the standard deviation. For the evaluation of regression equations in the optimization by RSM, Statgraphics Plus 5.1 (Statpoint Technologies, Inc. USA) was used.

\section{Results and Discussion}

\section{Selection of independent variables for optimization}

In the literature, statistical experimental design has been used to optimize the production of various types of recombinant proteins (Farliahati et al. 2010; Larentis et al. 2012; Sekar et al. 2018). In this work, RSM was used to increase biomass yields of recombinant $E$. coli harbouring plasmid pET15b with gene for influenza virus NA. Key factors found to affect E. coli biomass yields were carbon and nitrogen sources (Farliahati et al. 2010; Sekar et al. 2018) and based to our preliminary studies (data not shown) also the phosphate source. Therefore, the effect of these three factors on final biomass yield were evaluated (Fig. 1).
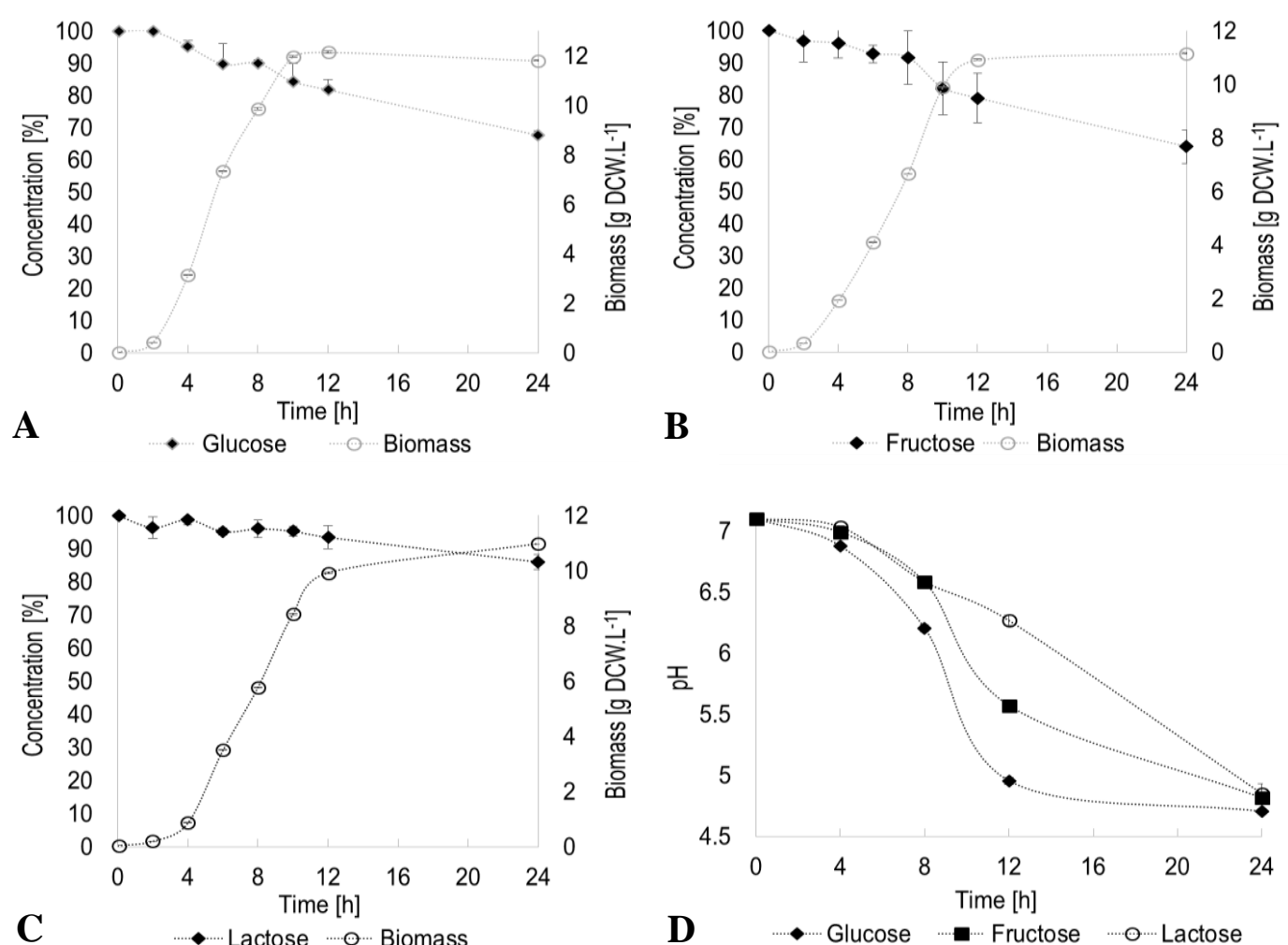

Fig. 1. The kinetics of E. coli growth in propagation media with glucose (A), fructose (B) and lactose (C) as carbon sources (respectively). Effect of carbon source on $\mathrm{pH}$ of medium (D). Data represent mean values of three replicates. 


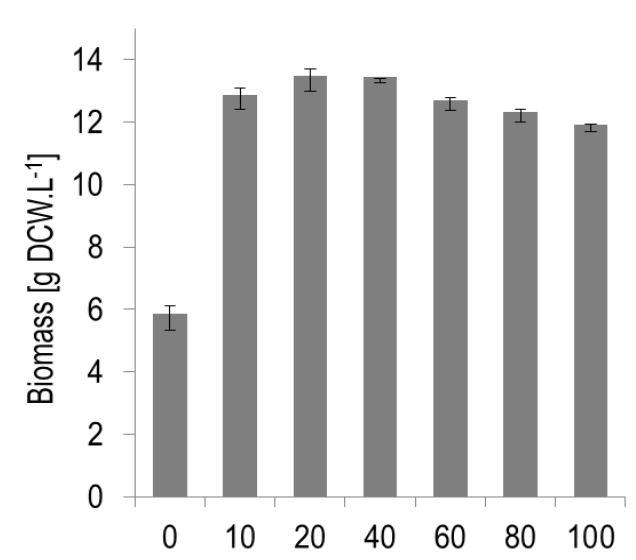

$\mathbf{A}$

Glucose concentration [mM]

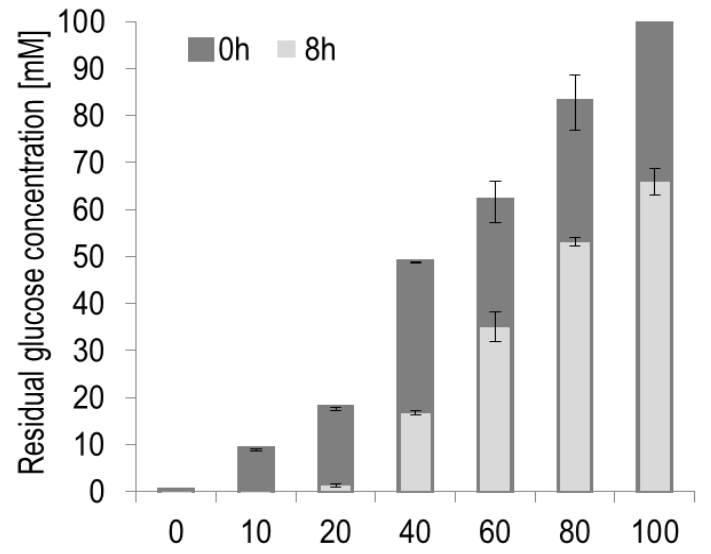

B

Glucose concentration [mM]
Fig. 2. The effect of glucose concentration on biomass production of $E$. coli (A) and its residual concentration (B) after $8 \mathrm{~h}$ of cultivation. Data represent mean values of three replicates.
The best carbon source for $E$. coli biomass production was glucose $\left(11.81 \pm 0.03 \mathrm{~g} \mathrm{DCW.L^{-1 }}\right)$. Glucose has been widely described as the appropriate substrate for the cultivation of E. coli (Wang et al. 2015; Jing et al. 2018; Lee et al. 2018) however, as is shown Fig. 1, recombinant E. coli was able to utilize effectively also pentose (fructose) and disaccharide (lactose); both of these carbon sources resulted in similar production of biomass $\left(11.16 \pm 0.01\right.$ and $10.97 \pm 0.00 \quad \mathrm{~g} \mathrm{DCW} . \mathrm{L}^{-1}$, respectively). E. coli cells entered the stationary phase of growth after 12 hours of cultivation in propagation media with glucose and fructose (Fig. 1 A, B), presumably due to decreased $\mathrm{pH}$ in these media (Fig. 1D). The consumption of carbon sources can lead to the production of organic acids, predominantly acetic acid, up to a concentration in the range of $50-100 \mathrm{mM}$. These concentrations are usually considered to cause the inhibition of growth (Pinhal et al. 2019) and low level of protein expression (Wang et al. 2016). The final $\mathrm{pH}$ values of media with different carbon sources were comparable ( 4.8). Therefore, glucose was selected as the main carbon source for followup experiments.

The concentration of selected carbon source is another parameter affecting biomass production. Therefore, the effect of glucose concentration in the range of $0-100 \mathrm{mM}$ to biomass production was evaluated. Glucose depletion was monitored after 8 hours (Fig. 2), as increased organic acid production inhibits bacterial growth (Fig. 1).

It was observed that $20-40 \mathrm{mM}$ of glucose stimulated bacterial growth (Fig. 2A). Farliahati et al. (2010) found that the combination of both glucose $(80 \mathrm{mM})$ and inorganic nitrogen source is the best choice for E. coli biomass production. Although, Larentis et al. (2012) suggested that the

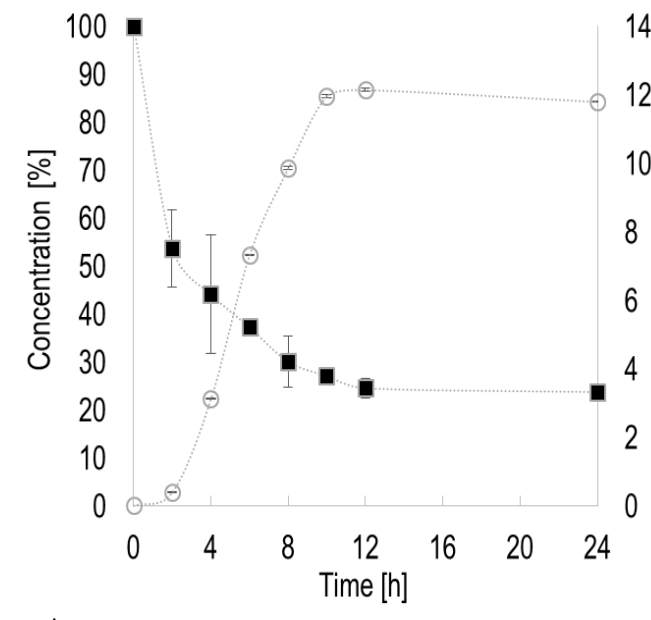

A

- Ammonium sulfate $\quad \odot \cdot$.... Biomass
B

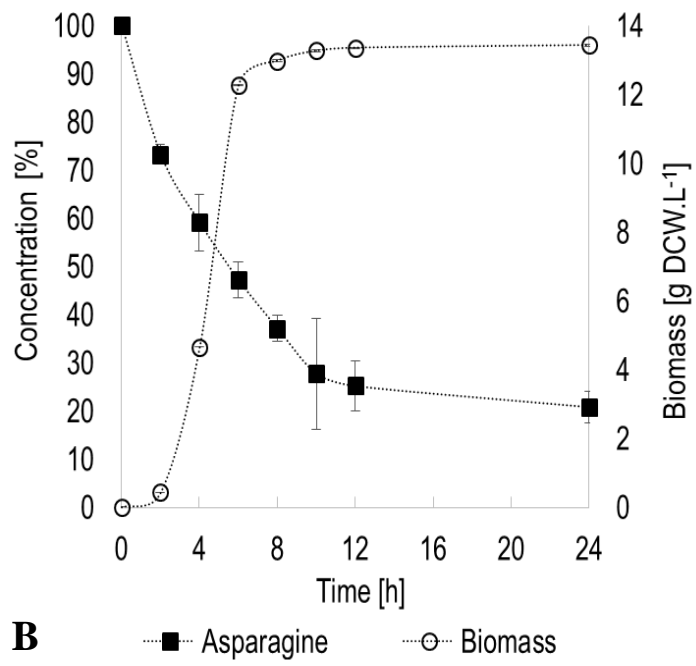

Fig. 3. Kinetics of E. coli growth in media with ammonium sulphate (A) and asparagine (B). Data represent mean values of three replicates. 


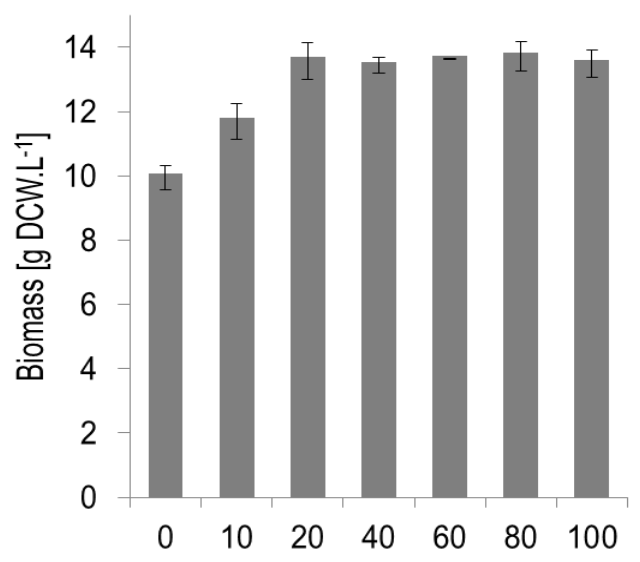

A

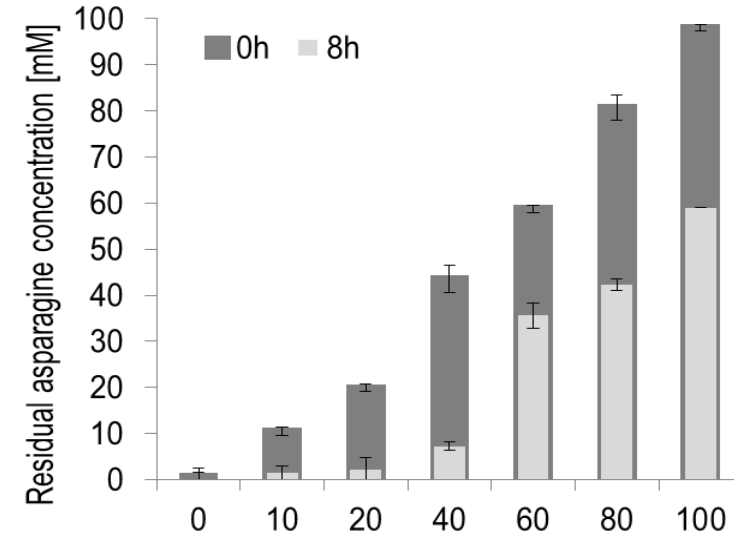

B

Asparagine concentration [mM]
Fig. 4. The effect of asparagine concentration on biomass production of $E$. coli $(\mathbf{A})$ and its residual concentration (B) after $8 \mathrm{~h}$ of cultivation. Data represent mean values of three replicates. lower concentration of glucose $(40 \mathrm{mM})$ in medium is beneficial to $E$. coli biomass production and glucose was almost depleted in the medium. Maximum glucose depletion in the propagation medium plays a crucial role in the subsequent production of recombinant NA, since high glucose concentrations cause the suppression of corresponding gene expression (Potvin et al. 2012; Celik et al. 2012). Glucose concentration range of 20 to $40 \mathrm{mM}$, representing the most suitable conditions for biomass production, was associated with significant reduction of glucose levels in the propagation medium (Fig. 2B).

The choice of nitrogen source and its concentration are among the other factors influencing biomass yield. The appropriateness of nitrogen source, namely ammonium sulphate and asparagine, was tested (Fig. 3).

Our results are in the contrasts to previous studies
(Chubukov et al. 2014; Wang et al. 2016) in which ammonium belongs to the preferred nitrogen source for $E$. coli. The higher $E$. coli biomass yield was observed in propagation medium with asparagine as

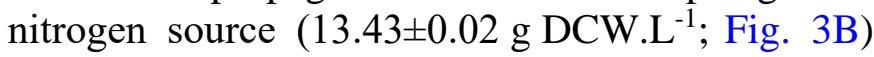
than in medium with ammonium ions in the form of ammonium sulphate $\left(11.81 \pm 0.01 \mathrm{~g}\right.$ DCW.L ${ }^{-1}$; Fig. 3A). Bren et al. (2016) found that amino acid as the nitrogen source in a medium supported the growth of $E$. coli. Therefore, the amino acid asparagine was selected as nitrogen source for further experiments and the effect of its different concentration in propagation media was tested (Fig. 4).

The asparagine concentration range of $40-60 \mathrm{mM}$ stimulated bacterial growth, but this effect was absent at higher concentrations (Fig. 4A). Almost complete depletion of the nitrogen source in propagation media containing asparagine

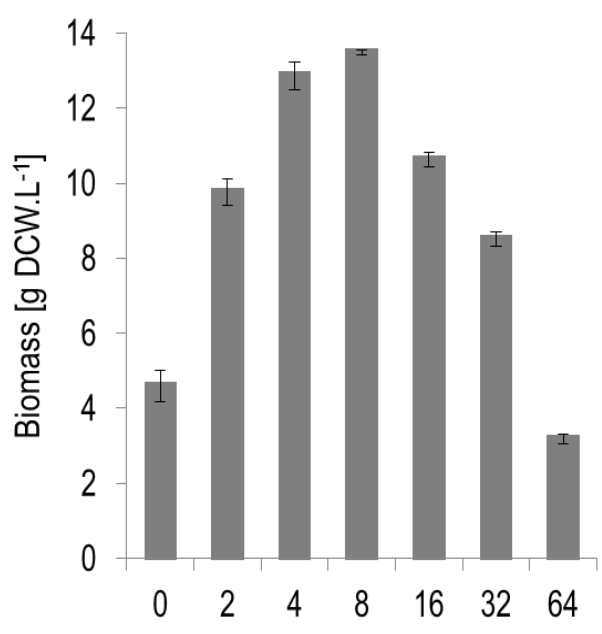

A Phosphate concentration [mM]

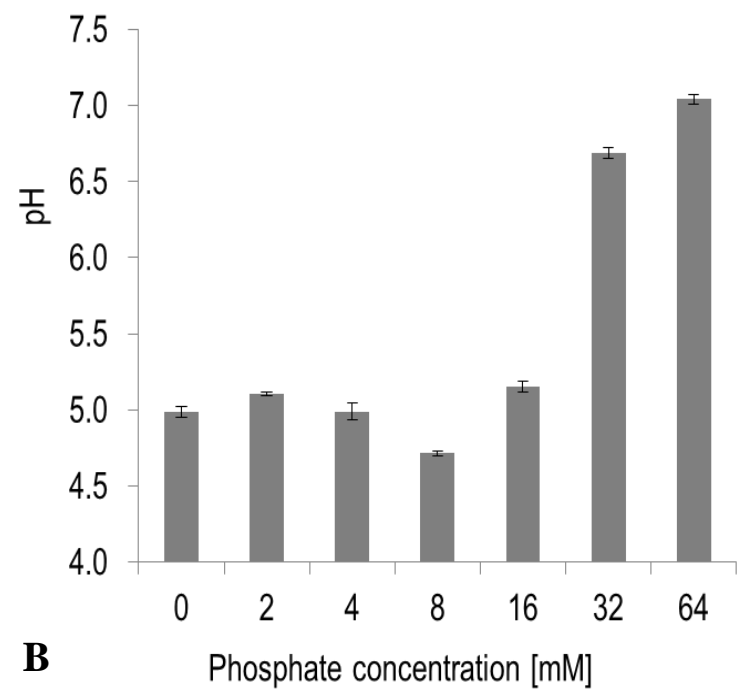

Fig. 5. The effect of phosphate concentration on biomass production of E. coli (A) and final $\mathrm{pH}$ of propagation media (B) after $8 \mathrm{~h}$ of cultivation. Data represent mean values of three replicates. 
Table 2. The combination of tested factors with their level codes from RSM and their effect on biomass production.

\begin{tabular}{|c|c|c|c|c|}
\hline \multirow{2}{*}{$\begin{array}{l}\text { Run } \\
\text { No. }\end{array}$} & \multicolumn{3}{|c|}{ Factor concentration $[\mathrm{mM}]^{\mathrm{a}}$} & \multirow{2}{*}{$\begin{array}{c}\text { Biomass } \\
{\left[\text { g DCW.L }{ }^{-1}\right]}\end{array}$} \\
\hline & Glucose & Asparagine & Phosphates & \\
\hline 1 & $50(1)$ & $40(-1)$ & $18(1)$ & $9.97 \pm 1.30$ \\
\hline 2 & $30(-1)$ & $80(1)$ & $18(1)$ & $12.19 \pm 0.44$ \\
\hline 3 & $50(1)$ & $80(1)$ & $10(-1)$ & $11.65 \pm 1.24$ \\
\hline 4 & $30(-1)$ & $40(-1)$ & $10(-1)$ & $9.49 \pm 0.12$ \\
\hline 5 & $40(0)$ & $60(0)$ & $14(0)$ & $16.21 \pm 0.91$ \\
\hline 6 & $30(-1)$ & $80(1)$ & $10(-1)$ & $11.12 \pm 0.64$ \\
\hline 7 & $50(1)$ & $80(1)$ & $18(1)$ & $12.36 \pm 1.12$ \\
\hline 8 & $30(-1)$ & $40(-1)$ & $18(1)$ & $11.48 \pm 0.44$ \\
\hline 9 & $40(0)$ & $60(0)$ & $14(0)$ & $16.61 \pm 0.88$ \\
\hline 10 & $50(1)$ & $40(-1)$ & $10(-1)$ & $8.65 \pm 0.59$ \\
\hline 11 & $23.27(-1.682)$ & $60(0)$ & $14(0)$ & $11.09 \pm 0.12$ \\
\hline 12 & $40(0)$ & $60(0)$ & $20.69(1.682)$ & $11.28 \pm 0.13$ \\
\hline 13 & $40(0)$ & $60(0)$ & $7.31(-1.682)$ & $8.69 \pm 0.17$ \\
\hline 14 & $40(0)$ & $93.46(1.682)$ & $14(0)$ & $9.59 \pm 0.16$ \\
\hline 15 & $40(0)$ & $26.53(-1.682)$ & $14(0)$ & $8.93 \pm 0.43$ \\
\hline 16 & $56.73(1.682)$ & $60(0)$ & $14(0)$ & $10.11 \pm 0.32$ \\
\hline 17 & $40(0)$ & $60(0)$ & $14(0)$ & $16.57 \pm 0.55$ \\
\hline
\end{tabular}

${ }^{a}$ in brackets the level codes are given.

in the concentration range of $10-40 \mathrm{mM}$ was observed (Fig. 4B).

One way to eliminate the problem of undesirable organic acid production is to modify the ionic strength of the buffer. In this study, PBS (phosphatebuffered saline) was used as the source of phosphate and the buffer (Fig. 5). Our results indicate that $\mathrm{pH}$ values of propagation media were maintained at phosphate concentrations of 32 and $64 \mathrm{mM}$ (Fig. 5B). With the decrease in salt concentration in the solution, the $\mathrm{pH}$ value decreases. However, it should be noted that the phosphate concentration positively influenced the biomass yield in the range of 4 to $16 \mathrm{mM}$ (Fig. 5A). The low biomass yields were observed in propagation media with increasing the phosphate concentrations. Scheidle et al. (2011) obtained similar results. The high concentration of phosphates increases the osmolality values and significantly reduces the growth rate of $E$. coli cells. Therefore, the suitable phosphate concentration is in the range of $4-16 \mathrm{mM}$ for both evaluated variables (Fig. 5).

\section{Optimization of propagation medium}

Based on preliminary experiments, we have chosen the factors affecting biomass yield and optimization using RSM to find the optimal conditions for maximum E. coli biomass yields (Table 2). The calculated coefficient of determination $\left(R^{2}\right)$ for biomass yields was 0.97 thus the model could explain $97 \%$ of the total variations in the experimental data. Biomass yields varied in the range of $8.65-16.61 \mathrm{~g}$ DCW.L $\mathrm{L}^{-1}$ (Table 2). The residual glucose and asparagine concentrations and the final $\mathrm{pH}$ of the propagation medium were selected as additional dependent variables. Recombinant protein production in E. coli host is a two-step process; in the second step the minimization of glucose concentration is needed prior to the induction of $\mathrm{T} 7$ promoter in the recombinant (pET15b) plasmid. In the experiments at center point of independent variables, glucose was almost completely consumed, with residual glucose concentrations of $6.65-7.25 \mathrm{mM}$. The coefficient of determination for residual glucose concentration as dependent variable was 0.99 . The residual concentration of asparagine varied in the range of $5.93-44.59 \mathrm{mM}$ with $R^{2}$ value of 0.98 . The final $\mathrm{pH}$ of propagation media varied in the range of $4.60-5.47$ with $R^{2}$ of 0.88 . The final $\mathrm{pH}$ proportionally decreased by $E$. coli growth and was associated with glucose and phosphate concentrations (data not shown). For better understanding of interactions between selected variables, the 3D surface plots are shown in Fig. 6. The third variable, phosphate concentration, was set as the constant $(14 \mathrm{mM}$; Fig. 6). Table 3 summarizes the regression coefficients and analysis of variances for biomass 
Table 3. Results of variance analysis and regression coefficients of the predicted second order polynomial models of biomass and residual concentration of glucose and asparagine.

\begin{tabular}{lccccc}
\hline Effect & Factor $^{\mathbf{a}}$ & Biomass & $\begin{array}{c}\text { Residual glucose } \\
\text { concentration }\end{array}$ & $\begin{array}{c}\text { Residual asparagine } \\
\text { concentration }\end{array}$ & pH \\
\hline Constant & & -59.509 & 276.306 & 140.318 & 8.073 \\
\hline Linear & $\mathrm{A}$ & 1.3307 & $\mathbf{- 5 . 6 0 2 7}$ & -2.8562 & -0.0647 \\
& $\mathrm{~B}$ & $\mathbf{0 . 6 6 7 3}$ & -2.4879 & $\mathbf{- 1 . 0 1 3 8}$ & -0.0134 \\
& $\mathrm{C}$ & $\mathbf{3 . 9 4 5 2}$ & -14.0071 & -8.1134 & $\mathbf{- 0 . 2 8 1 2}$ \\
\hline Quadratic & $\mathrm{AA}$ & $\mathbf{- 0 . 0 1 7 8}$ & $\mathbf{0 . 0 8 7 3}$ & $\mathbf{0 . 0 3 0 3}$ & 0.0009 \\
& $\mathrm{BB}$ & $\mathbf{0 . 0 0 5 7}$ & $\mathbf{0 . 0 2 0 8}$ & $\mathbf{0 . 0 0 6 9}$ & 0.0001 \\
& $\mathrm{CC}$ & $\mathbf{- 0 . 1 2 5 0}$ & $\mathbf{0 . 4 8 8 8}$ & $\mathbf{0 . 2 7 9 2}$ & $\mathbf{0 . 0 1 0 9}$ \\
\hline Interaction & $\mathrm{AB}$ & $\mathbf{0 . 0 0 1 9}$ & -0.0044 & 0.0123 & -0.0001 \\
& $\mathrm{AC}$ & $\mathbf{- 0 . 0 0 3 2}$ & -0.0077 & -0.0131 & $-7.8 .10^{-5}$ \\
& $\mathrm{BC}$ & $\mathbf{- 0 . 0 0 2 4}$ & 0.0060 & 0.0156 & 0.0002 \\
\hline
\end{tabular}

${ }^{\mathrm{a}}$ Concentration of glucose $-\mathrm{A}$; asparagine $-\mathrm{B}$; phosphates $-\mathrm{C}$

Statistically significant differences (at $p<0.05$ ) are shown bold.

yields, glucose and asparagine concentrations and final $\mathrm{pH}$ of propagation medium.

For biomass yields, asparagine and phosphate concentrations had the significant positive linear influence $(p<0.05)$ (Table 3). The increase of asparagine concentration from 60 to $80 \mathrm{mM}$ caused the decrease of biomass yield (Fig. 6A). All tested independent variables had negative quadratic effect to biomass yields $(p<0.05)$ and positive quadratic effect to residual glucose and asparagine concentrations $(p<0.05)$.
Glucose concentration had negative linear effect to residual glucose concentration in propagation media after the E. coli cultivation $(p<0.05)$ (Table 3). The increase of glucose concentration resulted in higher residual glucose concentration (Fig. 6 B). The higher residual glucose concentration can be a problem to produce recombinant protein due to the suppression of $\mathrm{T} 7$ promoter. Not surprisingly, asparagine concentration had a negative linear effect $(p<0.05)$ on the residual concentration of asparagine (Table 3 ),

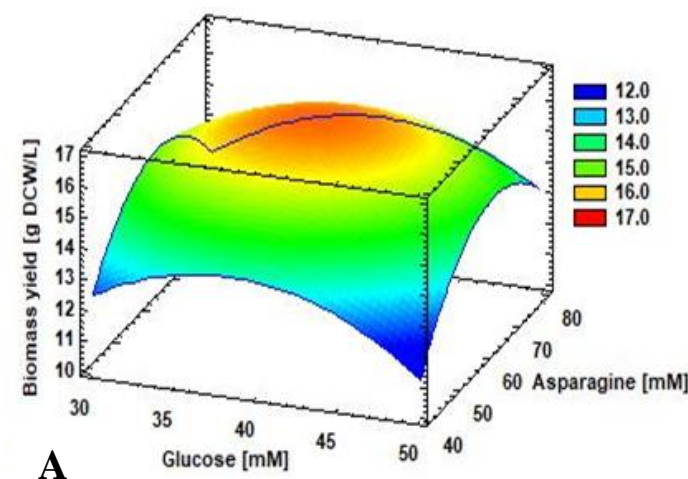

A

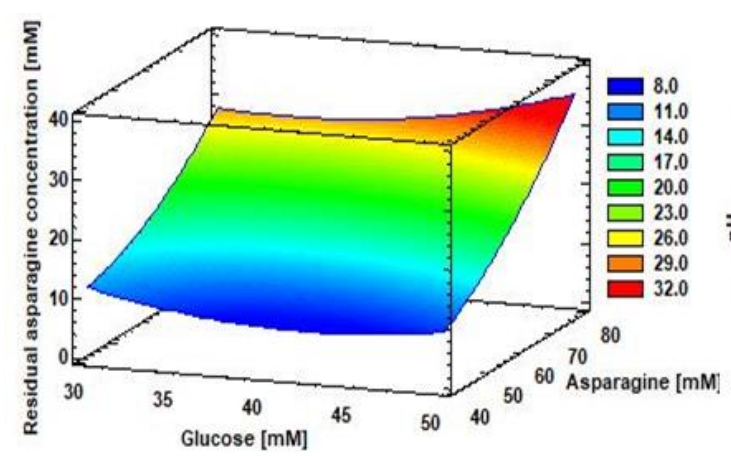

C

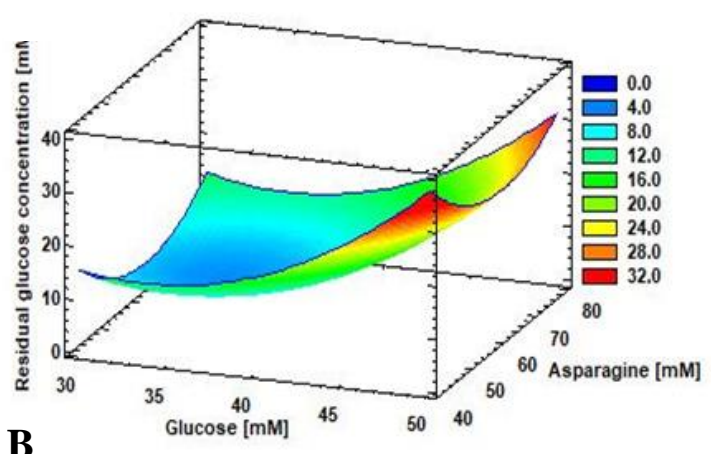

B

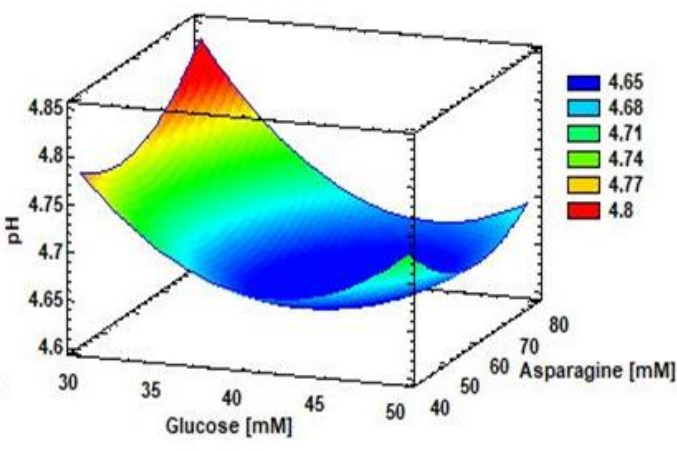

D
Fig. 6. 3D-surface plots showing the effect of glucose and asparagine concentrations on the biomass yield (A), effect of residual concentrations of glucose (B), asparagine and effect of $\mathrm{pH}$ of propagation medium (D). 
Table 4. Predicted and experimental values of biomass yield, residual glucose and residual asparagine at conditions optimal for maximum biomass yield.

\begin{tabular}{lccc}
\hline & $\begin{array}{c}\text { Biomass } \\
\text { [g DCW.L-1 }\end{array}$ & $\begin{array}{c}\text { Residual glucose concentration } \\
{[\mathbf{m M}]}\end{array}$ & $\begin{array}{c}\text { Residual asparagine } \\
\text { concentration [mM] }\end{array}$ \\
\hline $\begin{array}{l}\text { Predicted value } \\
\text { Experimental value }\end{array}$ & 16.55 & 6.63 & 17.01 \\
\hline RSM error [\%] & $15.91 \pm 0.43$ & $6.27 \pm 0.72$ & $17.20 \pm 2.55$ \\
\hline
\end{tabular}

similarly as observed for glucose (Fig. 6C). For final $\mathrm{pH}$ of propagation medium, phosphate concentration had negative linear $(p<0.05)$ and positive quadratic effects $(p<0.05)$ (Table 3$)$. Higher phosphate concentration allows to maintain the stable $\mathrm{pH}$ value in propagation medium (Fig. 6D). Moreover, as shown Fig. 6D, the final pH f propagation medium affects glucose concentration, and that is in good agreement with results of Kleman and Strohl (1994). The final $\mathrm{pH}$ of propagation medium was higher at lower glucose concentration (Fig. 6D).

\section{Verification of model}

According to RSM model, the highest yield of $E$. coli biomass can be reached in the propagation medium with glucose concentration of $39.37 \mathrm{mM}$, asparagine concentration of $62.68 \mathrm{mM}$ and phosphate concentration of $14.80 \mathrm{mM}$. Optimal conditions for biomass yield were confirmed experimentally (Table 4).

There was no significant difference between predicted and experimental values of all tested dependent variables $(p<0.05)$, suggesting this mathematical model can be exploited for maximum E. coli biomass yield in the first step of fermentation strategy. Moreover, biomass yield obtained in our modified optimized propagation medium was nearly 16 and $40 \%$ higher than in complex media used as a standard culture media for $E$. coli cells, namely Terrific broth (TB) and LB, respectively. Compared to defined media such as M9 and Riesenberg minimal medium (Kangwa et al. 2015), we achieved more than $50 \%$ higher biomass yield using our optimized medium.

It is commonly observed that the higher yield of biomass in batch cultivation is associated with lower amplification rate of pDNA compared to LB medium (O'Kennedy et al. 2003). Therefore, the yield of pET15b-neu obtained from cells cultivated in optimized medium was compared to pET15b-neu obtained from cells cultivated in LB medium. The yield of pET15b-neu from cells cultivated in optimized propagation medium $\left(1.40 \pm 0.16 \mu \mathrm{g} . \mathrm{g}^{-1}\right)$ was $22.86 \%$ higher as from cells obtained from the cultivation in LB medium $\left(1.08 \pm 0.14 \mu \mathrm{g} . \mathrm{g}^{-1}\right)$. Wood et al. (2017) suggested that high concentration of yeast extract in LB medium has impact on higher pDNA yield. In the case of optimized propagation medium used in this study, the asparagine amino acid may be involved in the induction of plasmid amplification as it was observed for amino acids such as leucine, glycine and histidine (Dorward et al. 2019).

\section{Conclusions}

The results of the present study confirm that the key factors for the propagation of Escherichia coli BL21 (DE3)pLys are the concentration of glucose as carbon source, concentration of asparagine as nitrogen source and concentration of phosphates. The RMS model was able effectively to describe the experimental data. The optimal concentration of selected factors such as glucose, asparagine and phosphate concentrations are 39.37, 62.68 and $14.80 \mathrm{mM}$, respectively. The predicted and experimental values further showed the adequacy of this model. At the optimal conditions, the yield of E. coli biomass was 16 and $40 \%$ higher than in TB and LB, respectively. These results suggested that optimized propagation medium for $E$. coli biomass production can be the suitable tool for effective recombinant protein production at relative high level. Moreover, arginine in propagation medium was probably involved in the induction of plasmid amplification.

\section{Acknowledgement}

This work was supported by research grants of the Slovak 
Research and Development Agency APVV-17-0239 and Fund for Research Support of the University of SS. Cyril and Methodius in Trnava FPPV-06-2019.

\section{Conflict of Interest}

The authors declare that they have no conflict of interest.

\section{References}

Bren A, Park, JO, Towbin BD, Dekel E, Rabinowitz JD, Alon U (2016) Glucose becomes one of the worst carbon sources for $E$. coli on poor nitrogen sources due to suboptimal levels of cAMP. Sci. Rep. 6: e24834.

Celik E, Calik P (2012) Production of recombinant proteins by yeast cells. Biotechnol. Adv. 5: 1108-1118.

Chubukov V, Sauer U (2014) Environmental dependence of stationary-phase metabolism in Bacillus subtilis and Escherichia coli. Appl. Environ. Microbiol. 9: 29012909.

Dorward A, O'Kennedy RD, Folarin O, Ward JM, KeshavarzMoore E (2019) The role of amino acids in the amplification and quality of DNA vectors for industrial applications. Biotechnol. Prog. 12: e2883.

Doyle M, Hashem AM, Li C, Van Domselaar G, Larocque L, Wang J, Smith D, Cyr T, Farnsworts A, He R, Hurt AC, Brown EG, Li X (2013) Universal anti-neuraminidase antibody inhibiting all influenza A subtypes. Antiviral. Res. 100: 567-574.

Fakruddin M, Mohammad MR, Bin Mannan KS, Chowdhury A, Hossain MN (2012) Critical factors affecting the success of cloning, expression, and mass production of enzymes by recombinant $E$. coli. ISRN Biotechnol. 13: 590587.

Farliahati MR, Ramanan RN, Mohamad R, Puspaningsih NNT, Ariff AB (2010) Enhanced production of xylanase by recombinant Escherichia coli $\mathrm{DH} 5 \alpha$ through optimization of medium composition using response surface methodology. Ann. Microbiol. 60: 279-285.

Ghosalkar A, Sahai V, Srivastava A (2008) Optimization of chemically defined medium for recombinant Pichia pastoris for biomass production. Bioresour. Technol. 99: 7906-7910.

Hadházi Á, Li L, Bailly B, Maggioni A, Martin G, Dirr L, Dyason JC, Thomson RJ, Gao GF, Borbás A, Ve T, Pascolutti M, von Itzstein M (2018) A sulfonozanamivir analogue has potent anti-influenza virus activity. ChemMedChem 13: 785-789.

Horga LG, Halliwell S, Castiñeiras TS, Wyre C, Matos CFRO, Yovcheva DS, Kent R, Morra R, Williams SG, Smith DC, Dixon N (2018) Tuning recombinant protein expression to match secretion capacity. Microb. Cell Fact. 17:199.

Jing K, Tang Y, Yao C, Del Rio-Chanona EA, Ling X, Zhang D (2018) Overproduction of L-tryptophan via simultaneous feed of glucose and anthranilic acid from recombinant Escherichia coli W3110: Kinetic modeling and process scale-up. Biotechnol. Bioeng. 115: 371-381.

Kangwa M, Yelemane V, Polat AN, Gorrepati KDD, Grasselli M, Fernández-Lahore M (2015) High-level fed-batch fermentative expression of an engineered Staphylococcal protein A based ligand in E. coli: purification and characterization. AMB Expr. 5: 1-10.

Kendall PA (1963) Use of the ninhydrin reaction for quantitative estimation of amino groups in insoluble specimens. Nature 197: 1305-1306.

Kleman G, Strohl W (1994) Acetate metabolism by Escherichia coli in high-cell-density fermentation. Appl. Environ. Microbiol. 60: 3952-3958.

Larentis AL, Nicolau JFMQ, Argondizzo APC, Galler R, Rodrigues MI, Medeiros MA (2012) Optimization of medium formulation and seed conditions for expression of mature PsaA (pneumococcal surface adhesin A) in Escherichia coli using a sequential experimental design strategy and response surface methodology. J. Ind. Microbiol. Biotechnol. 39: 897-908.

Lee HW, Lee HS, Kim CS, Lee JG, Kim WK, Lee EG, Lee HW (2018) Enhancement of L-threonine production by controlling sequential carbon-nitrogen ratios during fermentation. J. Microbiol. Biotechnol. 28: 293-297.

Miller GD (1959) Use of dinitrosalicyl acid regent for determination of reducing sugar. Anal. Chem. 31: 426428.

Nallaiyan S, Abbadorai RSAJ, Sundaramoorthy S, Nelson J, Veluvarthy S, Sanyasi V (2010) Production and application of recombinant haemagglutinin neuraminidase of Newcastle disease virus. Asian Pac. J. Trop. Med. 3: 629-632.

Nikerel IE, Öner E, Kirdar B, Yildirim R (2006) Optimization of medium composition for biomass production of recombinant Escherichia coli cells using response surface methodology. Biochem. Eng. J. 32: 1-6.

O'Kennedy RD, Ward JM, Keshavarz-Moore E (2003) Effects of fermentation strategy on the characteristics of plasmid DNA production. Biotechnol. Appl. Biochem. 37: 83-90.

Pinhal S, Ropers D, Geiselmann J, de Jong H (2019) Acetate metabolism and the inhibition of bacterial growth by acetate. J. Bacteriol. 201: e00147-19.

Potvin G, Ahmad A, Zhang Z (2012) Bioprocess engineering aspects of heterologous protein production in Pichia pastoris: A review. Biochem. Eng. J. 64: 91-105.

Rosano GL, Ceccarelli EA (2014) Recombinant protein expression in Escherichia coli: advances and challenges. Front Microbiol. 5: 172.

Scheidle M, Dittrich B, Klinger J, Ikeda H, Klee D, Büchs J (2011) Controlling $\mathrm{pH}$ in shake flasks using polymer-based controlled-release discs with pre-determined release kinetics. BMC Biotechnol. 11: 25.

Sekar A, Shin Y, Jeong H, Kim K (2018) Statistical optimization of culture medium to produce recombinant viral protein by Escherichia coli host for diagnostic kit to detect human immunodeficiency virus (HIV) infection. Biochem. Biophys. Res. Commun. 4: 666-671.

Udommaneethanakit T, Rungrotmongkol T, Frecer V, Seneci P, Miertuš S, Bren U (2014) Drugs against avian influenza a virus: design of novel sulfonate inhibitors of neuraminidase N1. Curr. Pharm. Des. 20: 3478-3487.

Wang J, Wen B, Xu Q, Xie X, Chen N (2015) Optimization of carbon source and glucose feeding strategy 
for improvement of L-isoleucine production by Escherichia coli. Biotechnol. Biotechnol. Equip. 29: 374-380.

Wang J, Yan D, Dixon R, Wang YP (2016) Deciphering the principles of bacterial nitrogen dietary preferences: a strategy for nutrient containment. MBio. 7: e00792-16. Wood WN, Smith KD, Ream JA, Lewis LK (2017) Enhancing yields of low and single copy number plasmid DNAs from $E$. coli cells. J. Microbiol. Methods 133: 46-51. 